\title{
Bisexuals need not apply: a comparative appraisal of refugee law and policy in Canada, the United States, and Australia
}

\author{
Sean Rehaag* \\ Osgoode Hall Law School, York University, Toronto, Canada
}

\begin{abstract}
This paper offers an analysis of refugee claims on grounds of bisexuality. After discussing the grounds on which sexual minorities may qualify for refugee status under international refugee law, the paper empirically assesses the success rates of bisexual refugee claimants in three major host states: Canada, the United States, and Australia. It concludes that bisexuals are significantly less successful than other sexual minority groups in obtaining refugee status in those countries. Through an examination of selected published decisions involving bisexual refugee claimants, the author identifies two main areas for concern that may partly account for the difficulties that bisexual refugee claimants encounter: the invisibility of bisexuality as a sexual identity, and negative views held by some refugee claims adjudicators towards bisexuality as well as the reluctance of some adjudicators to grant refugee status to sexual minorities who differ from gay and lesbian identities as traditionally understood.
\end{abstract}

Keywords: bisexuality; sexual orientation; refugee; asylum; law; credibility; Canada; Australia; United States

The world is not to be divided into sheep and goats ... It is a fundamental of taxonomy that nature rarely deals with discrete categories. Only the human mind invents categories and tries to force facts into separated pigeon-holes. The sooner we learn this concerning human sexual behavior the sooner we shall reach a sound understanding of the realities of sex. ${ }^{1}$

\section{Introduction}

Bisexuality tends to be invisible in human rights practice and discourse, even in areas that are otherwise comparatively sensitive to sexual minority issues. ${ }^{2}$ For example, at the time of writing, the European Human Rights Reports lists 68 cases that mentioned lesbians or homosexuals, but only four that mentioned bisexuals. ${ }^{3}$ Similarly, the Canadian Human Rights Tribunal referred to lesbians or homosexuals in 24 decisions, but to bisexuals in only two decisions. ${ }^{4}$ An equally revealing picture of the invisibility of bisexuality is evident in the names of prominent non-governmental organisations fighting for the human rights of sexual minorities. Consider, for example, the International Gay and Lesbian Human Rights Commission, ${ }^{5}$ the International Gay and Lesbian Association, ${ }^{6}$ the National Gay and Lesbian Task Force, ${ }^{7}$ the Gay and Lesbian Rights Lobby, ${ }^{8}$ the Lesbian and Gay Equality Project, ${ }^{9}$ and Equality for Gays and Lesbians. ${ }^{10}$

\footnotetext{
*Email: srehaag@osgoode.yorku.ca
} 
In light of such invisibility, this paper aims to bring greater attention to bisexuality in one particular area of international human rights: international sexual minority refugee law.

An individual who is outside his or her country of origin, and who has a well-founded fear of persecution on account of his or her sexual orientation, meets the international legal definition of a refugee and is eligible for refugee status. ${ }^{11}$ However, as I will demonstrate in this paper, bisexuals who allege a feared persecution on account of their sexual identity are frequently unable to secure refugee status. I argue that among the primary causes of the difficulties bisexual refugee claimants encounter are negative views held by some refugee claims adjudicators towards bisexuality, as well as the reluctance of some adjudicators to grant refugee status to sexual minorities who differ from gay and lesbian identities as traditionally understood.

My argument will proceed by first providing a brief introduction to international sexual minority refugee law. Then, I will examine the experiences of bisexual refugees in three major host states: Canada, the United States, and Australia. Through both quantitative and qualitative analysis of these experiences, I will demonstrate that bisexual refugee claimants have more difficulty securing refugee status than do other groups of sexual minorities. Finally, I will examine some of the reasons why bisexuals encounter difficulties securing refugee status.

Before turning to my main argument, it is pertinent to first address the terminology used in this paper. Debates regarding appropriate labels for sexual behaviours, sexual identities, and sexual orientations are one of the mainstays of discussions about what human rights have to say about sexual minorities. ${ }^{12}$ One source of these debates is that, regardless of which terminology one chooses to embrace, it will inevitably fail to accord with the selfunderstanding of many of those who are supposed to be covered by the terminology. There have, for example, been sharp disagreements over terms such as MSM (men who have sex with men), WSW (women who have sex with women), 'homosexual', 'gay', LGBT (lesbian, gay, bisexual, and transgender), and 'queer'. ${ }^{13}$ Some of the concerns expressed over such terms include whether a term occludes distinct sexual identities and complex intersectional considerations related to gender, class, race, language, religion, physical ability, HIV status, and so on; ${ }^{14}$ whether one inappropriately conflates (or bifurcates) sexual behaviours and sexual identities; ${ }^{15}$ and whether one excludes particular groups that ought to be included. ${ }^{16}$ Moreover, cross-cultural dimensions add a further level of complexity to these debates, because even if one's chosen terminology is accepted within one community, it may be inappropriate in communities located in other regions of the world. ${ }^{17}$

In this paper, I adopt the general term 'sexual minorities'. I choose the term because it has relatively unsettled and imprecise boundaries. This imprecision is helpful, as it allows the term to include all persons seeking protection from persecution on account of heteronormativity, ${ }^{18}$ irrespective of their precise sexual identities or sexual behaviours. ${ }^{19}$

One further terminological matter remains: my use of the term 'bisexuality'. Debates about appropriate labels are, if anything, even more pronounced with respect to bisexuality than to other sexual minority identities. ${ }^{20}$ Once again, cross-cultural considerations muddy the waters. Some of those characterised in one locale as 'bisexual' may be viewed in others as 'homosexual' or 'heterosexual'. ${ }^{21}$ In the context of this paper, it is necessary to note in particular that a person who would otherwise identify as exclusively homosexual may be coerced into different-sex sexual relations or into adopting bisexual identities through hetero-normative persecution. ${ }^{22}$

This paper attempts to sidestep some of these debates over the definition of 'bisexuality' because my interest is not to set out a particular definition and advocate its use by refugee 
claims adjudicators. Rather, my interest is to explore how sexual minority refugee claimants whose cases involve allegations of non-gender-exclusive sexuality are treated in the refugee determination systems in several major host states. In this paper, therefore, I use the term 'bisexual' loosely to mean a person whose sexual orientation, sexual identity, or sexual behaviour is not directed exclusively towards persons of one particular sex or gender. $^{23}$

\section{International refugee law and sexual minorities}

It is well settled in international refugee law that non-citizens facing persecution abroad on account of their sexual orientations are eligible for refugee status. ${ }^{24}$ The 1951 Convention Relating to the Status of Refugees, ${ }^{25}$ however, does not explicitly include sexual orientation. The Convention defines a refugee as any person who

owing to well-founded fear of being persecuted for reasons of race, religion, nationality, membership of a particular social group or political opinion, is outside the country of his nationality and is unable, or owing to such fear, is unwilling to avail himself of the protection of that country. ${ }^{26}$

Some sexual minority refugees have - with varying degrees of success - attempted to argue that their fear of persecution stemmed from their 'political opinion' ${ }^{27}$ The argument has, thus far, proved to be particularly effective for human rights activists who encounter heteronormative persecution as a result of their efforts to enhance the rights of sexual minorities. ${ }^{28}$ Political opinion, however, has been interpreted very broadly in international refugee law to cover 'any opinion on any matter in which the machinery of State, government, and policy may be engaged'. ${ }^{29}$ As a result, one could plausibly argue that 'political opinion' covers sexual minorities who face persecution for challenging both traditional gender norms as well as the inevitability of heterosexuality. With respect to the former (i.e. traditional gender norms), the United Nations High Commission for Refugees (UNHCR) Guidelines on Gender-Related Persecution state that political opinion 'may include an opinion as to gender roles. It would also include non-conformist behaviour which leads the persecutor to impute a political opinion. ${ }^{30}$ This is significant because persecution targeting sexual minorities often aims to 'foster and maintain "appropriate" gender role behaviour'. ${ }^{31}$ Meanwhile, with regard to the latter (i.e. challenging the inevitability of heterosexuality), the argument would find some support in the commonly made claim that the heterosexually structured family is the fundamental socio-economic unit, one that is supported through a variety of state policies. ${ }^{32}$ Sexual minorities, by their very existence, may be understood as challenging both the heterosexual family and the state policies that support it. In other words, sexual minorities may have political opinions regarding gender roles and the heterosexual family imputed to them, and may be persecuted on that basis. ${ }^{33}$

One might also plausibly contend that hetero-normative persecution sometimes involves not only persecution on grounds of 'political opinion' but also persecution on grounds of 'religion'. ${ }^{34}$ The UNHCR Guidelines on Gender-Related Persecution, for example, state that

[i]n certain States, the religion assigns particular roles or behavioural codes to women and men respectively. Where a woman does not fulfil her assigned role or refuses to abide by the codes, and is punished as a consequence, she may have a well-founded fear of being persecuted for reasons of religion. Failure to abide by such codes may be perceived as evidence that a woman holds unacceptable religious opinions regardless of what she actually believes. ${ }^{35}$ 
Just as women who are persecuted for transgressing gender roles or behavioural codes prescribed by religious dogmas may - irrespective of their actual religious beliefs ${ }^{36}$ be understood as facing persecution on grounds of religion, so too can sexual minorities. ${ }^{37}$ Indeed, as Nicole LaViolette notes, many sexual minority refugee claims involve fears of persecution where the claimant's ' $[\mathrm{h}]$ omosexuality is not only perceived as non-conformity to gender-specific roles but also ... a crime against religion' ${ }^{38}$ The argument would seem especially warranted where the agents of persecution are in one way or another tied to religious institutions - which is not unlikely given the longstanding hetero-normative traditions in most major world religions. It would also be worth pursuing such an argument in countries where religious and state institutions are not sharply divided. ${ }^{39}$

Although persecution on grounds of either religion or political opinion presents avenues for securing refugee status that are, in principle, open at least to some sexual minorities facing hetero-normative persecution, it is much more common for sexual minority refugee claimants to argue that they meet the refugee definition because they face persecution on grounds of their 'membership in a particular social group'. ${ }^{40}$

One of the leading cases on what exactly constitutes a 'particular social group' is the Canadian Supreme Court decision, Ward v. Canada ${ }^{41}$ In Ward, Justice La Forest explained that there were three distinct types of 'particular social groups' for the purpose of the refugee definition:

(1) groups defined by an innate or unchangeable characteristic;

(2) groups whose members voluntarily associate for reasons so fundamental to their human dignity that they should not be forced to forsake the association; and

(3) groups associated by a former voluntary status, unalterable due to its historical permanence. $^{42}$

Offering examples of each of the three types of social groups, Justice La Forest stated that ' $[t]$ he first category would embrace ... sexual orientation' ${ }^{43}$ In other words, sexual minorities facing persecution qualify for refugee protection as 'particular social groups' because, according to Justice La Forest, sexual orientation is an 'innate or unchangeable personal characteristic'. ${ }^{44}$

This passage has been cited with approval by courts in jurisdictions around the world ${ }^{45}$ and by the UNHCR Guidelines on Social Group Claims. ${ }^{46}$ However, there has been some recent movement away from this approach to sexual minority refugee jurisprudence.

Following Ward, a number of commentators have sharply critiqued Justice La Forest's reliance on the purported 'innate or immutable' nature of sexual orientation. ${ }^{47}$ According to these commentators, there are both strategic and symbolic benefits in grounding sexual minority refugee protection within the second category of 'particular social groups' identified in Ward: groups that associate 'for reasons so fundamental to their human dignity that they should not be forced to forsake the association. ${ }^{48}$ It is worth noting that this second category in Ward - which I will call the fundamental human dignity approach - has been given a slightly modified interpretation in subsequent international refugee law, most significantly through the UNHCR Guidelines on Social Group Claims. ${ }^{49}$ According to these Guidelines, the focus of the fundamental human dignity approach is not on whether members of a particular social group actually 'voluntarily associate', but rather on the question of whether the characteristic that the group shares is 'fundamental to identity, conscience or the exercise of one's human rights'..$^{50}$

The strategic advantage of embracing the fundamental human dignity approach is that the approach insulates sexual minority refugee protection from any possible shifts in 
research in science or social sciences on the 'causes' of sexual orientation. Views on the 'causes' of sexual orientation have long been hotly contested by scientists and social scientists alike. Many researchers suggest that sexual orientation is either related to genetics or to early childhood experiences (or to some combination of the two). Thus, they understand sexual orientation as by and large a fixed psychosocial characteristic. ${ }^{51}$ Other researchers, however, suggest that sexual orientation can and does change over time. Admittedly, some of such research is associated with those who controversially assert that homosexuality is a psychological condition that can be 'cured"52 through so-called 'conversion therapy' or 'sexual reorientation therapy ${ }^{53}$ As a study on political agendas in conversion therapy notes,

Current approaches tend to utilize religious and psychodynamic principles that define homosexuality as a 'condition' that results when a child does not receive sufficient love through the attachment to the same-sex parent ... For the sake of salvation, sexual reorientation programs tend to rely on the power of God and prayer to help the repentant homosexual strengthen willpower, reduce desire, and limit behavior... Heterosexual marriage and children are promised, which sexual reorientation therapists consider a healthy adaptation to a heterosexual world. ${ }^{54}$

However, some of the research finding that sexual orientation is mutable has emerged from scholars who do not hold disparaging views about homosexuality. Rather, these scholars emphasise the socially contingent and shifting aspects of human sexuality - including heterosexuality - and argue that human sexuality is too complex to be fully captured by models that hold that people simply 'are' homosexual or heterosexual (or any other sexual identity). ${ }^{55}$ Indeed, one of the primary aims of these scholars - often called 'queer theorists' - is to elucidate the power politics at play in what they view as the processes of social regulation that produce individuals who 'perform' naturalised sexual identities. ${ }^{56}$

What I want to emphasise here is that the debate over the 'immutability' of sexual orientation remains controversial and neither side of the debate has an exclusive claim to represent the views held by sexual minorities. In this context, it seems unwise to use the presumed 'immutability' of sexual orientation as the reason why sexual minorities facing hetero-normative persecution are entitled to refugee status. The risk is that, if the view of sexual orientation advocated by those on the 'mutability' side of the debate becomes dominant, then sexual minorities facing persecution will no longer meet the refugee definition. Nancy Knauer cautions against the risky strategy of tying sexual minority rights to a particular strain of evidence in science or social sciences regarding the nature and causes of sexual orientation:

By premising their rights claims ... on assertions of immutable status, pro-gay advocates have entrusted the success of a major social and political movement to the reliability of a few inconclusive studies concerning, inter alia, the size of the hypothalamus in the cadavers of gay men and the inner ears of lesbians. ${ }^{57}$

One strategic advantage, then, of grounding sexual minority refugee claims on the foundational principle that no one should be required to change their sexual orientations, rather than on the idea that no one can change their sexual orientations, is that sexual minorities will be able to secure refugee status irrespective of the ebbs and flows of the debates on the 'causes' of sexual orientation.

Just as important as this strategic advantage of the fundamental human dignity approach is that the immutability approach to sexual minority refugee protection carries problematic symbolic implications. To see these implications, let us consider why Justice La Forest 
attached relevance to whether sexual orientation is an immutable characteristic. It is important to note, in this regard, that Justice La Forest inferred the three types of 'particular social groups' mentioned above from the human rights commitments animating international refugee law. ${ }^{58}$ One of these human rights commitments inheres in the basic objection to differential treatment based on characteristics for which human beings cannot normatively be held responsible. If they are not responsible for their sexual orientations - if sexual orientations are, in other words, immutable personal characteristics - then differential treatment based on sexual orientation runs foul of this objection. Yoshino characterises these sorts of arguments as involving what he calls the 'immutability defense'. ${ }^{59}$ As Yoshino puts it, '[g]ays often defend their homosexuality by characterizing it as an immutable trait ... Immutability has exonerative force because of the widely held belief that it is abhorrent to penalize individuals for matters beyond their control. ${ }^{60}$

Compare the message the immutability defence approach sends with that which inheres in the alternative foundation for sexual minority protection, the fundamental human dignity approach, which holds that no human beings should be required to change their sexual orientations. The latter approach sends the message that sexual orientation is so closely connected to a person's fundamental human dignity that persecution aimed at enforcing "compulsory heterosexuality" ${ }^{61}$ and traditional gender norms ${ }^{62}$ is a human rights violation of such magnitude as to trigger refugee protection. Rather than presenting sexual minorities as unpopular minorities in need of protection because individuals are not responsible for their sexual orientations, this approach presents hetero-normative persecution as an impermissible trespass upon a person's fundamental human dignity. ${ }^{63}$

In recent years, courts and refugee claims tribunals in several jurisdictions have begun to embrace this alternative approach to sexual minority jurisprudence, perhaps due to its strategic and symbolic advantages. For example, in Hernandez-Montiel v. I.N.S., ${ }^{64}$ the United States Court of Appeals for the Ninth Circuit held that sexual minorities fell within both the first and second categories of 'particular social groups' identified in Ward. ${ }^{65}$ That is to say, one reason why sexual minorities persecuted abroad are entitled to refugee status and asylum in the United States is that 'sexual orientation and sexual identity ... are so fundamental to one's identity that a person should not be required to abandon them, ${ }^{66}$ Tribunals in Australia ${ }^{67}$ and New Zealand ${ }^{68}$ have come to similar conclusions and have refused to consider sexual minority refugee protection solely through the lens of protection for groups defined by innate and unchangeable characteristics. ${ }^{69}$

In principle, then, the ultimate rationale for sexual minority refugee protection appears to be shifting away from the contention that sexual orientation is an immutable characteristic, and towards the view that persecutory enforcement of compulsory heterosexuality and traditional gender norms is an infringement of fundamental human dignity. However, closer attention to case law reveals that sexual minority refugee claims continue in practice to be measured against relatively rigid and immutable understandings of sexual orientations. Nowhere is this clearer than in the experience of bisexual refugee claimants. ${ }^{70}$

\section{The experience of bisexual refugee claimants in selected host states}

Bisexual refugee claimants' experience, while varying to some degree across host states, shares two major features: (1) their presence in the host states' refugee jurisprudence is largely invisible and (2) they face extremely low refugee claim success rates. Both these features are evident in the experience of bisexual refugee claimants in three major host states: Canada, the United States, and Australia. 


\section{Canada}

In Canada, the earliest published case explicitly involving a bisexual refugee claimant was decided in $2000 .^{71}$ The decision involved a refugee claimant from Mexico who selfidentified as a "bisexual man who prefers men and being a transvestite ${ }^{72}$ and who had been repeatedly brutalised by the Mexican police. ${ }^{73}$ The claimant obtained refugee status, largely on the basis of persuasive country condition evidence involving frequent reports of violence directed towards transvestites in Mexico. ${ }^{74}$

However, in the following years, other bisexual refugee claimants have been largely unsuccessful in obtaining refugee protection. For example, according to a recent study undertaken by the author, no explicitly bisexual refugee claimant was granted refugee status in reported Canadian refugee decisions between 2001 and $2004 .^{75}$ In evaluating this figure, it should be noted that the study identified only 11 reported refugee decisions involving bisexuals, out of a total of 115 reported sexual minority refugee decisions. ${ }^{76}$ Moreover, it should be borne in mind that only a small fraction of Canadian refugee decisions are published, and those that are published cannot be taken to be a representative sample of all refugee determinations. ${ }^{77}$

To get a clearer picture of how sexual minority refugee claims - including bisexual refugee claims - are actually being decided in Canada, it is possible to use a formal request through the Access to Information $\mathrm{Act}^{78}$ to obtain data directly from the database of the administrative tribunal responsible for refugee determinations in Canada, that is, the Immigration and Refugee Board (IRB). ${ }^{79}$

According to data acquired through a formal Access to Information request regarding refugee determinations by the IRB in $2006,{ }^{80}$ bisexual refugee claims made up approximately $8 \%$ of sexual minority refugee claims decided by the IRB in 2006 ( 44 out of 577 decisions). The success rate for sexual minority claimants (58\%) exceeded the average success rates at the IRB for the year (54\%). However, the success rate for bisexual refugee claimants $(39 \%)$ was significantly lower. It is, moreover, worth noting that while the success rates for gay male and lesbian claimants were virtually identical (60\%), cases involving gay men (424) significantly outnumbered cases involving lesbians (100). In cases involving bisexuals, male claimants (33) once again outnumbered female claimants (11), but whereas success rates for gay and lesbian claimants matched closely, success rates for male bisexual claimants $(33 \%)$ were lower than those for female bisexual claimants $(55 \%){ }^{81}$

The author's previous study, which examined all (that is, reported and unreported) sexual minority refugee decisions by the IRB in 2004, came to mostly similar conclusions. According to that study, bisexual refugee claims made up $7 \%$ of sexual minority claims (100 out of 1351 decisions). Moreover, the success rate in sexual minority refugee claims (49\%) slightly exceeded the average IRB success rates for the year (46\%), and far exceeded the success rate in bisexual refugee claims $(25 \%){ }^{82}$

It appears then that, notwithstanding the success of the claimant in the first reported refugee decision involving a bisexual in Canada, bisexual refugee claimants have had a difficult time obtaining refugee status in Canada, compared with both refugee claimants in general and sexual minority refugee claimants in particular. ${ }^{83}$

\section{United States}

Although Hernandez-Montiel v. INS, a leading US case, explicitly considered the possibility that framing sexual minority refugee law exclusively in terms of homosexuality and heterosexuality may be 'too restrictive, ${ }^{84}$ reported cases involving bisexual applicants 
for refugee status and asylum in the United States have been rare. ${ }^{85}$ Indeed, there has only been one federal court decision explicitly involving a bisexual applicant, and in that case the applicant's bisexuality was mentioned only in passing. ${ }^{86}$ Moreover, the first - and thus far only - United States Board of Immigration Appeals case involving an explicitly bisexual applicant for refugee status and asylum currently reported in legal databases was decided in $2007{ }^{87}$ In that case an HIV-positive bisexual from Mexico was unsuccessful in obtaining refugee status and asylum in the United States. ${ }^{88}$

There are currently no statistics available on unreported average grant rates in refugee applications in the United States involving sexual minorities. ${ }^{89}$ However, it is possible to get a sense of what such statistics might reveal by using information obtained from the Asylum Documentation Program (ADP) of the International Gay and Lesbian Human Rights Commission. ${ }^{90}$ From 1994 to 2007 , the ADP assisted sexual minority refugee claimants, and their advocates, by providing documentation on the conditions faced by sexual minorities in particular countries abroad. When the ADP was contacted for assistance, staff recorded details of their cases in a database. Where possible, the outcomes of the cases in which the ADP provided assistance were also recorded.

According to the ADP's internal database, ${ }^{91}$ bisexual cases were rarely reported to the $\mathrm{ADP}$. In fact, bisexual cases represented less than $1 \%$ of the cases involving sexual minority refugee claimants in the United States that were reported to the ADP from 1994 to 2007 (38 cases out of 4241). Cases involving bisexual men (35) were more frequently reported than those involving bisexual women (3), just as reported cases involving gay men (3576) were much more common than those involving lesbians (627).

As with the Canadian data, the grant rate for bisexuals (5\%) was significantly lower than the rate for gay men and lesbians $(17 \%)$ in cases where the final outcomes were reported to the ADP. However, caution must be exercised when interpreting these statistics. In particular, the reported grant rates likely significantly understated the actual grant rates in sexual minority refugee claims, in large part because, due to limited resources, the ADP was not able to systematically determine the outcomes of all cases in which they offered assistance. ${ }^{92}$ As a result, data regarding refugee claim outcomes are only available in $14 \%$ of the cases involving bisexuals, and $21 \%$ of the cases involving gay men and lesbians reported to the ADP. Nonetheless, it seems significant that in the data collected by the ADP, whereas the grant rates of gay men (17\%) and lesbians (17\%) matched closely, the grant rates of gay men and lesbians $(17 \%)$, on one hand, and bisexuals $(5 \%)$, on the other, diverge significantly.

\section{Australia}

As far back as 1997, Justice Kirby of the High Court of Australia ruled, obiter, that 'homosexual and bisexual men and women' qualify for asylum under the category of those who suffer persecution on account of their membership in a particular social group. ${ }^{93}$ This passage was then cited with approval by the Australian High Court in its 2003 decision holding that sexual minorities constituted a particular social group for the purposes of refugee law. ${ }^{94}$ A subsequent Federal Court decision also explicitly affirmed that 'bisexuals can form a particular social group for the purposes of refugee law'. ${ }^{95}$

Although it is clear, then, that bisexuals facing persecution are in principle eligible for refugee status in Australia, in practice reported refugee claims involving bisexuals appear to have been quite rare. A study of Australian sexual minority refugee determinations from 1994 to $2000,{ }^{96}$ undertaken by Jenni Millbank and Catherine Dauvergne, identified 204 sexual minority refugee determinations, out of which 161 involved men and 43 involved 
women. ${ }^{97}$ In only two of the identified cases ${ }^{98}$ "the claimants self-identified as "bisexual" in their applications. ${ }^{99}$ Moreover, in these two cases the Australian Refugee Review Tribunal (RRT), 'rather than considering bisexuals as a particular social group, assumed the applicants to be homosexual'. ${ }^{100}$ The authors of the study also identified two further cases ${ }^{101}$ where the applicants were identified by the RRT as either bisexual ${ }^{102}$ or ambiguous in their sexuality. ${ }^{103}$ In none of these four cases - all of which involved men - did the applicant succeed in securing refugee status. It is worth noting that during the same period the average grant rate in the Australian sexual minority refugee decisions identified by Millbank and Dauvergne was $22 \%,{ }^{104}$ with gay men (26\%) enjoying a significantly higher grant rate than lesbians $(7 \%){ }^{105}$

More recently, there have been some Australian cases where bisexual claimants have secured refugee status, ${ }^{106}$ or where federal courts have overturned negative RRT decisions involving bisexual claimants. ${ }^{107}$ Still - as with the experience of bisexuals in Canada and the United States - these positive decisions remain the exception, rather than the rule. ${ }^{108}$

\section{Analysis of the experience of bisexual refugee claimants}

My review of the experience of bisexual asylum claimants in Canada, the United States, and Australia has highlighted that bisexuals are largely invisible in refugee determination systems, and that bisexuals seem to have a more difficult time securing refugee status than other groups of sexual minorities. It is, thus, pertinent to attempt to account for these two central observations.

\section{Bisexual invisibility}

There is very little information currently available on bisexual refugee claimants in Canada, the United States, or Australia. To begin with, as we have seen, there are few reported bisexual refugee decisions, that is, decisions published in official law reports. As we have also seen, however, according to data obtained from Canada's IRB, approximately $7-8 \%$ of sexual minority refugee claims made in Canada were identified by the IRB as involving bisexuals. There is no reason to think that the proportion of bisexuals among sexual minority refugee claimants in the United States or Australia is any lower. The issue of why there have been few reported bisexual asylum decisions is, therefore, a puzzle to be explored.

While some refugee law scholars have discussed bisexuality within larger analyses of sexual minority refugee claims, there is relatively little scholarship that concentrates exclusively on bisexual refugee claims. ${ }^{109}$ One reason why bisexuals have drawn little attention in the area of international refugee law may be due to perceptions that refugee claims involving bisexuals are uncommon because decisions involving such claims have only infrequently been reported. This explanation, however, fails to fully account for the lack of attention to bisexual refugee claims as they arise. After all, the number of lesbian refugee claims is also low compared with the number of claims involving gay men, and yet significant scholarly attention has - quite rightly - been paid to analysing and attempting to improve refugee determinations involving lesbians. ${ }^{110}$ Moreover, one of the main preoccupations in the scholarly literature on lesbian refugee claimants is precisely to examine why women are under-represented in sexual minority refugee claims. ${ }^{111}$

In my view, a more persuasive explanation for the lack of attention to bisexual refugee claimants in both reported decisions and in refugee law scholarship relates to a broader social phenomenon identified by scholars who have engaged closely with bisexuality. 
That social phenomenon is that bisexuals tend to be invisible in - or actively erased from - both sexual minority and mainstream communities. ${ }^{112}$

Many theorists tie the invisibility of bisexuality to a naturalised conception of human sexuality, in which human beings are understood to be either essentially heterosexual or essentially homosexual. ${ }^{113}$ According to Kenji Yoshino, maintaining this naturalised binary understanding of human sexuality serves the interests of heterosexual communities, as heterosexuals inhabit a privileged position in this naturalised binary hierarchy. ${ }^{114}$ Gagnon, Greenblat, and Kimmel echo this view, noting that

Only a few thinkers [have begun] to consider what would happen if what appeared to be the most natural of all forms of conduct, the conventionalised sexual relations of women and men, was treated as problematic and the topic of history, anthropology, and sociology rather than biology, psychiatry, and individualist psychologies. To entertain the belief that the sexual desires of the majority are as much the result of a social construction as are the desires of all sexual minorities is a classic example of what is bad (perhaps even intolerable) to think, much less to practice. ${ }^{115}$

It is important to appreciate, however, that this naturalised binary is also useful to many in sexual minority communities. ${ }^{116}$ In particular, essentialised homosexual subject positions can form an important site for political mobilisation against heterosexist oppression. ${ }^{117}$ Moreover, in many states around the world, sexual minorities have resorted to essentialist accounts of sexual orientations in order to bring constitutional challenges to heterosexist discrimination. ${ }^{118}$ It is worth considering, in this regard, a remark by Justice Kirby, the first openly gay Justice of the Australian High Court:

\footnotetext{
The advent of the Human Genome Project and the likelihood that, in many cases at least, sexual orientation is genetically determined, make it unacceptable to impose upon those affected unreasonable legal discrimination or demands that they change. It was always unacceptable; but now no informed person has an excuse for blind prejudice and unreasonable conduct. If we are talking about the unnatural, demands that people deny their sexuality or try to change it, if it is part of their nature, are a good illustration of what is unnatural. An increasing number of citizens in virtually every Western democracy are coming inexorably to this
realisation. 119
}

Now, Justice Kirby did not intend to suggest that human beings are genetically predetermined to be either homosexual or heterosexual, to the exclusion of all other sexual identities. On the contrary, in both court decisions and extra-judicial writings, Justice Kirby regularly refers not only to gay men and lesbians, but also to bisexuals and other groups of sexual minorities. ${ }^{120}$ Nonetheless, bisexuality complicates the essentialist and even biological determinist - account of human sexuality at the heart of the above passage. It is this account of human sexuality that, according to Yoshino, both heterosexual and many sexual minority communities have an interest in maintaining. ${ }^{121}$

Bisexuality challenges the essentialist account of human sexuality in at least two ways. First, many - though by no means all ${ }^{122}$ - bisexuals understand their sexual identity as involving some degree of choice, and often a highly politicised choice at that. ${ }^{123} \mathrm{Liz} \mathrm{High-}$ leyman, for example, describes how she came to identify as bisexual in the following terms:

Some people become radicalised politically because of their oppression as gays, lesbians and bisexuals. Others questions their heterosexuality as a result of their radical politics ... It was within radical political circles, in fact, that I first got to know bisexual, gay and lesbian people. I began to wonder why so many people who shared my political ideals rejected 
traditional notions of gender and sexuality, and I started to question many of the assumptions I had grown up with. When I thought about it, it made little sense to rule out the romantic and sexual potential of half of humanity. ${ }^{124}$

Second, many bisexuals report that their sexual identity is fluid and undergoes shifts over time. Marie King, for example, notes that ' $[\mathrm{h}] \mathrm{aving}$ lived my life for a number of years as a heterosexual and then for an equally long period as a lesbian, I have lately arrived at a kind of bisexual synthesis'. ${ }^{125}$ Others, such as Dave Matteson, suggest that their sexual identity - or the identity that they present to others - shifts even more frequently in response to social context:

I made a decision fairly early in my public coming out to frequently use the word gay when speaking to the mainstream heterosexual community. I did not want to have my bisexuality seen as minimizing the side of me that is gay. On the other hand, when doing work in the gay community I have stressed being bisexual, to help fight the prejudice there against bisexuals. $^{126}$

Or, as Starhawk puts it in more colourful terms,

those of us who are bisexual, and honest, have to admit that our sexual orientation sometimes seems to change with the phases of the moon or the level of pollen in the air, or just with propinquity to whoever happens to be around. I honour the lesbian and gay activists who have made their sexual orientation a cornerstone of their identities, and respect the political need for doing so ... But if I'm honest about my own sexual identity, it has something to do with a deep reluctance to be pinned down. ${ }^{127}$

Taken together, because many in both heterosexual and sexual minority communities have an interest in preserving essentialist understandings of human sexuality, and because bisexuality challenges these understandings, bisexuality is often downplayed, ignored, or even erased. Yoshino calls this phenomenon 'the epistemic contract of bisexual erasure'. ${ }^{128}$ The result of this epistemic contract is that bisexuality is largely invisible in both heterosexual and sexual minority communities. ${ }^{129}$

It is worth reflecting on the possibility that the invisibility of bisexuality in the refugee determination systems in Canada, the United States, and Australia, as well as in some of the work of contemporary refugee law scholars, both partakes in and contributes to this epistemic contract of bisexual erasure.

\section{Low grant rates in bisexual refugee claims}

Once the invisibility of bisexual refugee claimants is challenged, one of the most pressing issues that needs to be explored is why bisexuals face much lower refugee claim grant rates than those involving gay men and lesbians in Canada, the United States, and Australia.

A full analysis of the low grant rates for bisexual refugee claimants would require an extensive review of unpublished refugee decisions. The methodological challenges involved in such a review render this enterprise beyond the scope of this paper. However, based on the few reported decisions involving bisexual refugee claimants, a few tentative observations can be made.

First and foremost, reported refugee decisions reveal troubling views about bisexuality held by refugee claims adjudicators. Perhaps the most flagrant example can be found in the comments made by an adjudicator at the Australian RRT in a case involving a bisexual 
refugee claimant from China. ${ }^{130}$ In this decision, after accepting that homosexuals constitute a particular social group for the purposes of the refugee definition, ${ }^{131}$ the RRT went on to note that,

by stressing at the hearing that he is bisexual, the Applicant has not satisfied the Tribunal that he is reconciled to homosexual activity, lifestyle or even social association, or that he has any kind of preternatural homosexual identity or tendencies. It seems to the Tribunal that if this case were about political opinion, it would be as if the Applicant were saying that, at heart, he was a little bit disposed towards democracy but also eager to support authoritarianism; if it were about religion, it would be as if the Applicant, at heart, were a little bit Christian and a little bit atheist. There is significant equivocation in the Applicant's evidence and it goes against him. ${ }^{132}$

To understand this passage, it is important to emphasise that the RRT went on to note that 'the notion of a group defined as "bisexuals" has been considered insofar as the homosexual side of bisexual[s] ... were an issue'. ${ }^{133}$ The RRT, in other words, was prepared to entertain the possibility that bisexuals may meet the refugee definition where they faced persecution because of their 'homosexual side'. However, the RRT simultaneously found that the mere assertion of bisexuality was sufficient evidence to hold that the claimant did not, in fact, have a 'homosexual side' (that is, he was not 'reconciled to homosexual activity, lifestyle or even social association' and did not have 'any kind of preternatural homosexual identity or tendencies'). ${ }^{134}$ The understanding of homosexuality that animated such a holding is one that sees homosexuality as the absence or antithesis of heterosexual desire. Combined with the notion that bisexuals are only eligible for refugee status to the extent that they will otherwise be persecuted on account of homosexuality, this understanding of homosexuality serves to erase the very possibility that bisexuals may be eligible for refugee status.

This case was admittedly an outlier in that, as we have seen, several refugee tribunals and courts have accepted bisexuality as a basis for refugee claims. However, troubling comments and findings made by adjudicators are not infrequent in refugee claims involving bisexuals. Sometimes the findings made by adjudicators in such claims are so disturbing that even the lawyers representing the governments will distance themselves from them. For example, in a recent Canadian federal court judicial review of a negative refugee determination involving an 18-year-old bisexual from Saint Lucia, "counsel for the Minister conceded that some of the ... findings were "silly" and that the [adjudicator]'s language was "inappropriate". ${ }^{135}$ The 'silliest' and most 'inappropriate' of the findings in question related to a purported inconsistency identified by the adjudicator in the claimant's failure to engage in sexual activity in Canada, notwithstanding her previous sexual experiences with both men and women:

The claimant testified that she has not been sexually active [in Canada]. She [says she] is underage to go to gay clubs and she is busy with going to school. It is difficult to believe how a person sexually active with a male and two females from the age of 14 is living a celibate life now. ${ }^{136}$

This comment is disturbing because it closely matches negative stereotypes about bisexuals as sexually voracious or 'pathologically promiscuous'. ${ }^{137}$ Indeed, in the cited passage the adjudicator appeared to reject the claimant's asserted bisexual identity merely because the claimant's behaviour (that is, 'celibacy') departed from these stereotypes. This indicates not only that individuals whose sexual identities depart from the stereotypes about human sexuality held by adjudicators may have their refugee claims improperly denied, but also that the underlying understanding of human sexuality held by some adjudicators continues to be 
premised upon immutability. More specifically, this particular adjudicator was simply unwilling to accept that the claimant's sexual behaviour might change in response to different circumstances; the adjudicator seemed to be saying that if the claimant really had sexual relations with both men and women from the age of 14, then she would necessarily continue to do so at the age of 18 , irrespective of the very different circumstances in which she now found herself.

Although explicit remarks involving such extremely negative views of bisexuality have been relatively rare in reported refugee decisions involving bisexuals, troubling views of bisexuality were nonetheless frequently implicit in the types of evidence that refugee claims adjudicators cited when assessing the sexual identities of refugee claimants. For example, in a Canadian case involving a woman from Iran, the IRB cited evidence that the claimant intended to marry a man to conclude that the claimant was not, in fact, a bisexual. As the adjudicator put it,

The claimant arrived in Canada with a male companion ... In response to the question as to whether they were planning to get married, the claimant replied, 'So far there is a commitment but officially we haven't signed a paper or anything.' ... [The claimant's] actions are those of a heterosexual woman. ${ }^{138}$

Similarly, in another Canadian case involving a woman from Hungary, the IRB held that the claimant was not a bisexual, partly based on evidence of prior different-sex sexual conduct:

The claimant came to Canada because allegedly she was persecuted, among other reasons, on account of her sexual orientation. However ... the evidence shows that since last year she has been living with her boyfriend. ${ }^{139}$

These decisions were seriously problematic, as they failed to understand the reality of bisexual experiences. Indeed, one of the common themes of literature on bisexuality is the challenge of having one's bisexual identity taken seriously when one is in a sexually exclusive long-term relationship. The difficulty bisexuals encounter in this regard is that one's sexual identity is often read with reference to the gender of one's current or recent sexual partner(s). Consider, for example, the frustration expressed by Ruth Colker, a leading bisexual theorist, with being perceived as heterosexual because of her marriage to a man: "in cases such as mine, most people probably just attach the label "married woman" to me with its assumptions about exclusive heterosexuality without even inquiring about my sexual orientation'. ${ }^{140}$ Similarly, as William Burleson notes, 'if a self-identified bisexual woman is in a monogamous relationship with another woman, she is now assumed to be lesbian'. ${ }^{141}$

In order to challenge these views, it is important to emphasise that although some bisexuals have multiple recent or concurrent sexual partners of various sexes/genders, ${ }^{142}$ others may be in long-term sexually exclusive relationships. ${ }^{143}$ Consider, for example, the following comments by Rifka Reichler:

I am a 23-year-old married Jewish woman. I have never slept with a woman, nor do I expect to. Yet, I am bisexual ... and participate in the bisexual community. The newspapers and newsletters I read, the conversations I have with friends, the buttons I hang in my study, and the organizations I join all affirm my bisexuality. The term bisexual affirms the part of me that loves women, now and in the future, regardless of who I am sleeping with. ${ }^{144}$ 
If one understands that sexual identity and sexual behaviour are not necessarily perfectly correlated, as the above comments by bisexual authors attest, then it seems unclear in what respect evidence that a refugee claimant maintains a sexually exclusive relationship could plausibly be read as challenging the credibility of his or her asserted bisexual identity. Rather, the fact that adjudicators in bisexual refugee claims cited such evidence suggests that they were actually concerned with establishing, not whether the claimant was bisexual, but rather where the claimant fit into an essentialist hetero/ homosexual binary.

A similar point can be made with regard to cases where evidence of same-sex sexual relationships was disregarded in assessing a refugee claimant's sexual minority identity. For example, in a recent Australian bisexual refugee case, the RRT, after noting that the male claimant had previously maintained sexual relationships with women, dismissed evidence regarding the claimant's ongoing sexual relationship with a man while he was in long-term immigration detention. ${ }^{145}$ The RRT in particular noted that

I do not accept that the Applicant is in fact bisexual ... I consider that his relationship with ... [another male immigration detainee] is simply the product of the situation where only partners of the same sex are available and says nothing about his sexual orientation. ${ }^{146}$

In another Australian bisexual refugee case involving a man from Pakistan, the RRT stated:

The Tribunal accepts that the Applicant might have enjoyed sexual play with other males when he was a teenager ... However, the Tribunal is not prepared to accept on the evidence before it that this was anything but a transient, youthful phase. ${ }^{147}$

Again, what is troubling about these remarks is that the adjudicators seemed to be preoccupied with uncovering the claimants' essential and unchangeable 'true' sexual identities. Evidence of same-sex sexual behaviour that the adjudicators understood as being affected by a particular social context - for example, youthful experimentation or sex-segregated incarceration - may therefore be disregarded. Thus, the following remarks by Millbank about the Australian Refugee Review Tribunal are apposite and can be extended to other refugee claims adjudication bodies:

In situations where the applicant was seen as having some choice, or their sexuality any way fluid or temporary - if they could be seen as bisexual, young, sexually inexperienced generally, or having had only limited same-sex-sexual experiences, the Australian tribunal, in particular, was very reluctant to accept them ... under the social group category. ${ }^{148}$

In the end, if these troubling comments in the few reported cases involving bisexual refugee claimants reflect the overall trend among the unpublished cases, then one possible explanation for the low refugee claim grant rates for bisexuals is that although in principle bisexuals who have a well founded fear of being persecuted for their sexual orientation are eligible for refugee status, in practice at least some refugee claims adjudicators will only grant refugee status to sexual minorities who display more traditionally understood sexual identities that fit within an essentialised homo/hetero binary. As previously mentioned, however, such a hypothesis needs to be tested further by reviewing decisions that were unpublished. 


\section{Conclusion}

This paper has sought to shed light on an area of international refugee law that seldom attracts much attention: refugee claims made by bisexuals. It has demonstrated that bisexuals outside their countries of origin who have a well-founded fear of persecution on grounds of their sexual orientation in principle meet the refugee definition. However, it has also shown that, at least in Canada, the United States, and Australia, bisexual refugee claimants are much less likely to succeed in securing refugee status than are other groups of sexual minorities. As few decisions involving bisexual refugee claimants are published, further empirical analysis of unpublished decisions should be undertaken to identify the causes of the low success rates in bisexual refugee claims. On the basis of the few decisions that were published, I hypothesise that such research would reveal that among the reasons for the low grant rates include (1) the invisibility of bisexuality and (2) the disparaging views of some refugee claims adjudicators on bisexuality and their willingness to grant refugee status to bisexuals only to such extent as their cases appear to match adjudicators' perceptions of homosexual or lesbian sexual identities.

Ultimately, we must bear in mind that the stakes in refugee determinations are immense. Negative and wrongly decided refugee claims will result in individuals being forcibly repatriated to countries where they will face persecution, torture, or even death. Accordingly, the current treatment of bisexual refugee claimants in Canada, the United States, and Australia provides cause for grave concern.

\section{Acknowledgements}

This paper was written while the author was a visiting researcher at the Asylum Documentation Program of the International Gay and Lesbian Human Rights Commission in San Francisco. He would like to thank Dusty Araujo and others at the Program for providing a congenial research environment. He would also like to thank the University of Toronto International Human Rights Program for its generous financial assistance.

\section{Notes}

1. Alfred Kinsey, Wardell Pomeroy, and Clyde Martin, Sexual Behavior in the Human Male (Philadelphia: W.B. Saunders, 1948), 639.

2. See generally Clare Hemmings, 'What's in a Name? Bisexuality, Transnational Sexuality Studies and Western Colonial Legacies', International Journal of Human Rights 11 (2007): 13. See also notes $112-29$ and accompanying texts below.

3. These figures were obtained by searching for 'homosexual or lesbian' and 'bisexual', respectively, using Westlaw-Ecarswell's electronic database entitled 'EHR-RPTS'. The search was conducted on 20 May 2008.

4. These figures were obtained by searching for 'homosexual or lesbian' and 'bisexual', respectively, using Quicklaw's electronic database entitled 'Canadian Human Rights Tribunal Decisions'. The search was conducted on 20 May 2008.

5. International Gay and Lesbian Human Rights Commission, http://www.iglhrc.org.

6. International Gay and Lesbian Association, http://www.ilga.org.

7. National Gay and Lesbian Task Force, http://www.thetaskforce.org.

8. Gay and Lesbian Rights Lobby, http://www.glrl.org.au.

9. Lesbian and Gay Equality Project, http://www.equality.org.za.

10. Égalité pour les gais et les lesbiennes, http://www.egale.ca.

11. See notes $24-70$ and accompanying texts below. In this paper I use the term 'refugee claim' to cover requests made for protection against deportation to face persecution (i.e. meaning that the refugee claimant is already present in the host state). The term thus covers, for example, what would be considered 'refugee claims' in Canada, as well as what are termed applications for 'asylum' or for 'withholding of removal' in the United States. The issue of requests for 
refugee protection or resettlement made from outside host states is beyond the scope of this paper.

12. See generally Judith Butler, Bodies that Matter: On the Discursive Limits of 'Sex' (New York: Routledge, 1993), 223-42; Francisco Valdes, 'Queers, Sissies, Dykes, and Tomboys: Deconstructing the Conflation of "Sex", "Gender" and "Sexual Orientation" in Euro-American Law and Society', California Law Review 83 (1995): 1; Elivra Arriola, 'Law and the Gendered Politics of Identity: Who Owns the Label "Lesbian"?', Hastings Women's Law Journal 8 (1997): 1; Sonia Katyal, 'Exporting Identity', Yale Journal of Law \& Feminism 14 (2002): 97.

13. For an excellent overview of debates over these terms in sexual minority communities, see 'Symposium on Linguistic Creativity in LGBT Discourse', World Englishes 17 (2002): 187.

14. Terms that aim at broad inclusivity - including, for example, 'queer', MSM, and WSW - are frequently critiqued along these lines. See, e.g., Viviane Namaste, Sex Change, Social Change: Reflections on Identity, Institutions, and Imperialism (Toronto: Women's Press, 2005), 21 ("'Queer" is quite specific to Anglo-American locations'); Rebecca Young and Ilan Meyer, "The Trouble with "MSM" and "WSW": Erasure of the Sexual-Minority Person in Public Heath Discourse', American Journal of Public Health 95 (2004): 1144.

15. Valdes, 'Queers, Sissies, Dykes, and Tomboys', 161-212.

16. Nancy Knauer, 'Gender Matters: Making the Case for Trans Inclusion', Pierce Law Review 6 (2007): 1 ('Lesbian and gay advocacy organizations officially began to incorporate transgender issues in the late 1990s, as signalled by the now ubiquitous "T" that appears at the end of the popular acronym "LGBT". However, the resulting alliance has been an uneasy one and the incorporation has been partial.')

17. See, e.g., Gilbert Herdt, 'Bisexuality and the Causes of Homosexuality: The Case of the Sambia', in Bisexualities: The Ideology and Practice of Sexual Conduct with Both Men and Women, ed. Erin Haeberle and Rolf Gindorf (New York: Continuum, 1998), 164 ('Sambia do not have a noun category either for homosexual or for heterosexual. They do not recognize in their history or culture that someone can be exclusively homosexual in partner selection, or exclusively heterosexual'). See also Sebastian Maguire, 'The Human Rights of Sexual Minorities in Africa', California Women's International Law Journal 35 (2004): 1.

18. Throughout this paper I refer to 'hetero-normative' persecution. I choose this terminology, rather than the more common 'homophobic' persecution, as it emphasises that the persecution participates in enforcing compulsory heterosexuality, and is not merely a persecutory reaction to an unpopular minority. Also, 'hetero-normative' persecution is a general term that (partly) encompasses other more specific forms of persecution targeting particular sexual minorities, including homophobia, bi-phobia, trans-phobia, etc.

19. The term, thus, covers not only homosexual, lesbian, bisexual, transsexual, and intersexed individuals, but also others who may be mistreated on the basis of their sexual identity or sexual behaviour. For example, one could argue that the term includes (but is not limited to) sex workers, adulterers, swingers, polyamorists, and sado-masochists. For a discussion of the applicability of international refugee law to some of these sexual minorities, see, e.g., Kristen Walker, 'New Uses of the Refugees Convention: Sexuality and Refugee Status', in The Refugees Convention 50 Years On, ed. Susan Kneebone (Aldershot: Ashgate, 2003), 251, 273-7.

20. For an excellent review on debates over the term 'bisexuality' see Kenji Yoshino, 'The Epistemic Contract of Bisexual Erasure', Stanford Law Review 52 (2000): 370.

21. Katyal, 'Exporting Identity', 153.

22. In the literature on bisexuality, these individuals are sometimes referred to as 'defence bisexuals': Yoshino, 'The Epistemic Contract of Bisexual Erasure', 371-2.

23. By phrasing my definition this way, I also hope to circumvent the unfortunate binary evoked by the term 'bisexuality', which problematically implies that all people fall into one of two (and only two) genders or sexes. For a critique of binary understandings of gender, see Kate Bornstein, Gender Outlaw: On Men, Women and the Rest of Us (New York: Vintage Books, 1994).

24. UNHCR, Guidelines on International Protection: Gender-Related Persecution within the Context of Article 1A(2) of the 1951 Convention and/or its 1967 Protocol Relating to the Status of Refugees, UN Doc. HCR/GIP/02/01, 7 May 2002; reproduced in International Journal of Refugee Law 14 (2002): 457, paras 15-16. See also James Hathaway, The Law of Refugee Status (Toronto: Butterworths, 1991), 163; Jenni Millbank, 'Imagining Otherness: 
Refugee Claims on the Basis of Sexuality in Canada and Australia', Melbourne University Law Review 26 (2002): 149.

25. 189 UNTS 150, entered into force on 22 April 1954.

26. Ibid., Art.1.A(2) (emphasis added).

27. Erik Ramanathan, 'Queer Cases: A Comparative Analysis of Global Sexual Orientation-Based Asylum Jurisprudence', Georgetown Immigration Law Journal 11 (1996): 26.

28. See, e.g., C.Y.T. (Re) [1998] CRDD No. 186.

29. Guy Goodwin-Gill and Jane McAdam, The Refugee in International Law, 3rd edn (Oxford: Oxford University Press, 2007), 87.

30. UNHCR, Guidelines on International Protection, para. 32. For a discussion arguing that gender norm non-compliance is often at the root of persecution experienced by sexual minorities, see Nicole LaViolette, 'Gender-Related Refugee Claims: Expanding the Scope of the Canadian Guidelines', International Journal of Refugee Law 19 (2007): 169.

31. Chris Kendall, 'Lesbian and Gay Refugees in Australia: Now that "Acting Discreetly" is No Longer an Option, will Equality be Forthcoming?', International Journal of Refugee Law 15 (2003): 718. See also LaViolette, 'Gender-Related Refugee Claims'.

32. See, e.g., International Covenant on Civil and Political Rights, Art. 23(1): 'The family is the natural and fundamental group union of society and is entitled to protection by society and the state.' For a discussion of the heterosexual nature of the types of families recognised under international law, see Kristen Walker, 'Capitalism, Gay Identity and International Human Rights Law', Australasian Gay and Lesbian Law Journal 9 (2000): 58, 68-70.

33. Nicole LaViolette, 'The Immutable Refugees: Sexual Orientation in Canada (A.G.) v. Ward', University of Toronto Faculty of Law Review 55 (1997): 29; Kristen Walker, 'Sexuality and Refugee Status in Australia', International Journal of Refugee Law 12 (2000): 178; Ramanathan, 'Queer Cases', 26.

34. For a general discussion of the possibilities of framing hetero-normative violence as persecution on account of religion, see Jeffrey Redding, 'Human Rights and Homo-sectuals: The International Politics of Sexuality, Religion, and Law', Northwestern University Journal of International Human Rights 4 (2005): 436.

35. UNHCR, Guidelines on International Protection, para. 25 (emphasis added).

36. For a persuasive analysis that draws on the UNHCR Guidelines to argue that persecution on grounds of religion is an appropriate category through which to assess refugee claims involving repressive gender norms, regardless of the actual religious beliefs of refugee claimants, see Karen Musalo, 'Claims for Protection Based on Religion or Belief', International Journal of Refugee Law 16 (2004): 212.

37. See generally LaViolette, 'Gender-Related Refugee Claims', 169-214.

38. Ibid., 202.

39. The UNHCR Guidelines note, however, that in such states persecution targeting those who fail to conform to repressive religious norms may be taken as persecution on grounds of religion or as persecution on grounds of political opinion: UNHCR, Guidelines on International Protection, para. 26.

40. Arwen Swink, 'Queer Refuge: A Review of the Role of Country Condition Analysis in Asylum Adjudications for Members of Sexual Minorities', Hastings International and Comparative Law Review 29 (2006): 254; Walker, 'Sexuality and Refugee Status in Australia', 178 esp. n. 9.

41. Ward v. Canada [1993] 2 SCR 689. See also Goodwin-Gill and McAdam, The Refugee in International Law, 10 (identifying Ward as 'one of the leading "social group" cases'); Walker, 'New Uses of the Refugees Convention', 265-6 (discussing the importance of Ward in the development of international refugee law).

42. Ward v. Canada, 739. Note that this definition was drawn in part from an earlier United States Board of Immigration Appeals decision, Matter of Acosta, 19 I \& N Dec. 211 (BIA 1985), 233.

43. Ward, ibid.

44. Ibid.

45. Hernandez-Montiel v. I.N.S., 225 F.3d 1084 (9th Cir., 2000), 1093; Islam v. Secretary of State for the Home Department Immigration Appeal Tribunal and Another [1999] UKHL 20.

46. UNHCR, Guidelines on International Protection: 'Membership of a Particular Social Group' within the Context of Article 1A(2) of the 1951 Convention and/or Its 1967 Protocol Relating to the Status of Refugees, HCR/GIP/02/02, 7 May 2002, para. 6. 
47. See, e.g., LaViolette, 'The Immutable Refugees'; Walker, 'Sexuality and Refugee Status in Australia', 209.

48. Ward v. Canada, 739.

49. UNHCR, Guidelines on International Protection, para. 11.

50. Ibid. See also European Union Council Directive 2004/83/ED of DATE April 2004, ch. 3, Art.10.1(d): 'a group shall be considered to form a particular social group where in particular ... members of that group share ... a characteristic or belief that is so fundamental to identity or conscience that a person should not be forced to renounce it'.

51. See, e.g., John Bailey, Michael Dunne, and Nicholas Martin, 'Genetic and Environmental Influences on Sexual Orientation and its Correlates in an Australian Twin Sample', Journal of Personality and Social Psychology 78 (2000): 524. For a general review of literature in social sciences on the 'causes' of sexual orientation, see Simon LeVay, Queer Science: The Use and Abuse of Research into Homosexuality (Cambridge, MA: MIT Press, 1996).

52. Julianne Serovich, Shonda Craft, Paula Toviessi, Rashmi Gangamma, Tiffany McDowell, and Erika Grafsky, 'A Systematic Review of the Research Based on Sexual Reorientation Therapy', Journal of Marital and Family Therapy 34 (2008): 227 (noting that conversion therapy aims 'to "cure" homosexuals by transforming them into heterosexuals').

53. For a discussion of conversion therapy, see Robert Spitzer, 'Can Some Gay Men and Lesbians Change their Sexual Orientation? 200 Participants Reporting a Change from Homosexual to Heterosexual Orientation', Archives of Sexual Behavior 32 (2003): 403; contra, Kenneth Cohen and Ritch Savin-Williams, 'Are Converts to be Believed? Assessing Sexual Orientation "Conversions"', Archives of Sexual Behavior 32 (2003): 427; Gregory Herek, 'Evaluating Interventions to Alter Sexual Orientation: Methodological and Ethical Considerations', Archives of Sexual Behavior 32 (2003): 438.

54. Lee Beckstead, 'Cures Versus Choices: Agendas in Sexual Reorientation Therapy', Journal of Gay and Lesbian Psychotherapy 5 (2001): 88.

55. For an excellent review of 'social constructivist' scholarship challenging the view of sexual orientation as immutable, see Edward Stein, ed., Forms of Desire: Sexual Orientation and the Social Constructivist Controversy (New York: Routledge, 1992). See also Michel Foucault, The History of Sexuality, Volume I: An Introduction (New York: Pantheon, 1978).

56. Janet Halley, 'Sexual Orientation and the Politics of Biology: A Critique of the Argument from Immutability', Stanford Law Review 46 (1994): 503; Butler, Bodies that Matter; Brenda Cossman, 'Sexuality, Queer Theory, and "Feminism after": Reading and Rereading the Sexual Subject', McGill Law Journal 49 (2004): 847.

57. Nancy Knauer, 'Science, Identity, and the Construction of the Gay Political Narrative', Law \& Sexuality 12 (2003): 6.

58. Ward v. Canada, 739: "The meaning assigned to "particular social group" in the Act should take into account the general underlying themes of the defence of human rights and antidiscrimination that form the basis for the international refugee protection initiative.'

59. Yoshino, 'The Epistemic Contract of Bisexual Erasure', 405.

60. Ibid.

61. Adrienne Rich, 'Compulsory Heterosexuality and Lesbian Existence', Signs 5 (1980): 631.

62. For an argument that hetero-normative persecution is best understood as targeting noncompliance with gender norms, see Kendall, 'Lesbian and Gay Refugees in Australia'.

63. See generally Halley, 'Sexual Orientation and the Politics of Biology'.

64. Hernandez-Montiel v. I.N.S.

65. The court explicitly cited Ward and adopted Justice La Forest's definition of 'particular social groups': ibid., 1093, n. 6. In adopting the Canadian definition the court resolved a previous conflict in American refugee law over whether 'particular social groups' had to involve voluntary association (Sanchez-Trujillo v. INS, 801 F.2d 1571 (9th Cir. 1986), 1576) or immutable characteristics (Matter of Acosta, 19 I. \& N. Dec. 211 (BIA 1985), 233).

66. Hernandez-Montiel v. I.N.S., 1093.

67. See, e.g., A v. Minister for Immigration and Ethnic Affairs (1997) 142 ALR 331; S395/2002 and S396/2002 v. Minister for Immigration and Multicultural Affairs (2003) ALR 112.

68. Refugee Appeal No. 1312/93 (30 August 1995); Refugee Appeal No. 74665/03 (7 July 2004).

69. Canada is an outlier in this regard. However, there is some support for a shift in this direction to be found in Canadian constitutional jurisprudence on sexual minority rights, particularly in decisions by Supreme Court Justice L'Heureux-Dubé. See, e.g., Egan v. Canada [1995] 2 
SCR 513, per L'Heureux-Dubé J., dissenting (esp. para. 89); Vriend v. Alberta [1998] 1 SCR 493, per L'Heureux-Dubé J., concurring (esp. para. 186); Trinity Western University v. British Columbia College of Teachers [2001] 1 SCR 772, per L'Heureux-Dubé J., dissenting (esp. para. 69).

70. There are, in fact, other areas of sexual minority refugee law where rigid understandings of human sexuality continue to influence refugee jurisprudence notwithstanding the dominance of the fundamental human dignity approach. Jenni Millbank, for example, argues that the frequently criticised requirement in the refugee jurisprudence of some jurisdictions - including the United Kingdom - that sexual minorities must try to avoid persecution in violently heteronormative societies by being 'discreet' is connected to a rigid understanding of human sexuality as a matter that is inherently or 'naturally' private: 'A Preoccupation with Perversion: The British Response to Refugee Claims on the Basis of Sexual Orientation 1989-2003', Social \& Legal Studies 14 (2005): 115

71. $B D K(R e)[2000]$ CRDD No. 72 .

72. Ibid., para. 8 .

73. Ibid., paras $2-3$.

74. Ibid., para. 7.

75. Sean Rehaag, 'Patrolling the Borders of Sexual Orientation: Bisexual Refugee Claims in Canada', McGill Law Journal 53 (2008): 59, 76.

76. Ibid, 69, 76-7.

77. Millbank, 'Imagining Otherness', 149.

78. RSC, 1985 , c. A-1.

79. Immigration and Refugee Protection Act, SC 2001, c. 27, s. 170(b).

80. The full data are available online: Sean Rehaag, 'New Refugee Claim Data \& IRB Member Grant Rates', http://www.ccrweb.ca/documents/rehaagdata.htm (accessed 1 November 2008). For a description of the methodology used to acquire and compile the data, as well as for a description of the limits to the data set, see Sean Rehaag, 'Troubling Patterns in Canadian Refugee Adjudication', Ottawa Law Review 39 (2008): 335.

81. In addition to cases involving gay men, lesbians, and bisexuals, there were nine sexual minority decisions that the Immigration and Refugee Board placed in a category labelled 'Other'. The grant rate in these cases was $56 \%$.

82. Rehaag, 'Patrolling the Borders of Sexual Orientation', 70-1.

83. For a fuller discussion of bisexual refugee claims in Canada, see ibid., 59-102.

84. Hernandez-Montiel v. I.N.S., 1093.

85. Jin Park, 'Pink Asylum: Political Asylum Eligibility of Gay Men and Lesbians under U.S. Immigration Policy', UCLA Law Review 42 (1995): 1115, n. 5: 'asylum claims based on bisexuality do not appear to be common'.

86. Ford v. Bureau of Immigration and Customs Enforcement's Interim Field Office Dir. for Det. and Removal, 294 F. Supp. 2d 655 (3d Cir. Pa., 2005), 656-7: 'Petitioner describes himself as bi-sexual with a greater homosexual inclination.'

87. In Re: Jesus-Jimenez Rodriguez, 2007 WL 1676897 (BIA, 24 April 2007), No. A71922463.

88. Ibid.

89. For general information about asylum grant rates in the United States, see Jaya Ramji-Nogales, Andrew Schoenholtz, and Philip Schrag, 'Refugee Roulette: Disparities in Asylum Adjudication', Stanford Law Review 60 (2007): 295.

90. As of the time of writing, the Asylum Documentation Program is no longer part of the International Gay and Lesbian Human Rights Commission. The Program has now joined the Heartland Alliance (National Immigration Justice Center).

91. The data were produced using a search through the Program database performed by the author at the Program office in San Francisco on 24 September 2007. It should be noted that in addition to the figures presented, the Program also assisted a significant number of refugee claimants (i.e. applicants for asylum or withholding of removal) whose cases raised issues related to transgender oppression or persecution targeting HIV-positive individuals.

92. Dusty Araujo, Asylum Documentation Coordinator, ADP, personal correspondence dated 24 January 2008 (on file with author).

93. A v. Minister for Immigration and Ethnic Affairs, 390.

94. S395/2002 and S396/2002, 126. 
95. VRAW and $V R A X$ v. Minister for Immigration and Multicultural and Indigenous Affairs [2004] FCA 1133, para. 1.

96. Jenni Millbank, 'Gender, Sex and Visibility in Refugee Claims on the Basis of Sexual Orientation', Georgetown Immigration Law Journal 18 (2003): 71. See also Catherine Dauvergne and Jenni Millbank, 'Burdened by Proof: How the Australian Refugee Review Tribunal Has Failed Lesbian and Gay Asylum Seekers', Federal Law Review 31 (2003): 299.

97. Millbank, 'Gender, Sex and Visibility in Refugee Claims on the Basis of Sexual Orientation', 73 , n. 11 .

98. RRT Reference: N95/07313 [1997] RRTA 2438 (27 June 1997); RRT Reference: N97/15882 [1997] RRTA 3396 (5 September 1997).

99. Millbank, 'Gender, Sex and Visibility in Refugee Claims on the Basis of Sexual Orientation', 93, n. 98.

100. Ibid.

101. Ibid.

102. RRT Reference: V97/06483 [1998] RRTA 27 (5 January 1998).

103. RRT Reference: V98/09111 [1999] RRTA 418 (22 February 1999).

104. Millbank, 'Gender, Sex and Visibility in Refugee Claims on the Basis of Sexual Orientation', 73 , n. 14.

105. Ibid., 75, n. 19.

106. See, e.g., RRT Reference: V02/14641 [2004] RRTA 351 (7 May 2004); RRT Reference: 061020474 [2007] RRTA 25 (7 February 2007).

107. See, e.g., VRAW and VRAX v. Minister for Immigration and Multicultural and Indigenous Affairs; SZAKD v. Minister for Immigration [2004] FMCA 78.

108. For examples of negative Australian decisions involving bisexuals, see, e.g., SZJSL v. Minister for Immigration and Multicultural Affairs and Another [2007] FMCA 313 (19 February 2007); SZGNJ v. Minister for Immigration and Multicultural and Indigenous Affairs and Another [2006] FMCA 91 (24 February 2006); SZEHT v. Minister for Immigration and Multicultural and Indigenous Affairs [2005] FCA 1468 (7 October 2005); SZENG and Another v. Minister for Immigration and Multicultural and Indigenous Affairs and Another [2005] FMCA 1435 (29 September 2005); SZEOE v. Minister for Immigration and Multicultural and Indigenous Affairs [2005] FCA 694 (31 May 2005); RRT Reference: N03/45936 [2003] RRTA 709 (31 July 2003); RRT Reference: N01/37929 [2003] RRTA 567 (20 June 2003); RRT Reference: N01/38642 [2003] RRTA 285 (31 March 2003); RRT Reference: N01/36734 [2002] RRTA 898 (8 October 2002).

109. For an example of a refugee law scholar who has addressed bisexuality in some detail, see Walker, 'Sexuality and Refugee Status in Australia', 187-8.

110. See, e.g., LaViolette, 'Gender-Related Refugee Claims'; Victoria Nelson, 'Homosexual or Female? Applying Gender-Based Asylum Jurisprudence to Lesbian Asylum Claims', Stanford Law and Policy Review 16 (2005): 417; Swink, 'Queer Refuge'; Millbank, 'Gender, Sex and Visibility in Refugee Claims on the Basis of Sexual Orientation'; Dauvergne and Millbank, 'Burdened by Proof'.

111. See esp. Millbank, 'Gender, Sex and Visibility in Refugee Claims on the Basis of Sexual Orientation'.

112. See, e.g., Clare Hemmings, Bisexual Spaces: A Geography of Sexuality and Gender (New York: Routledge, 2002), 82-90; Robyn Ochs, 'Biphobia: It Goes More than Two Ways', in Bisexuality: The Psychology and Politics of an Invisible Minority, ed. Beth Firestein (Thousand Oaks, CA: Sage, 1996), 225; Ruth Colker, Hybrid: Bisexuals, Multiracials and Other Misfits under American Law (New York: New York University Press, 1996), 15-21; Naomi Mezey, 'Dismantling the Wall: Bisexuality and the Possibilities of Sexual Identity Classification Based on Acts', Berkeley Women's Law Journal 10 (1995): 98.

113. Yoshino, 'The Epistemic Contract of Bisexual Erasure'; Halley, 'Sexual Orientation and the Politics of Biology'.

114. 'The Epistemic Contract of Bisexual Erasure', 402-4.

115. John Gagnon, Cathy Greenblat, and Michael Kimmel, 'Bisexuality: A Sociological Perspective', in Bisexualities: The Ideology and Practice of Sexual Conduct with Both Men and Women, ed. Erin Haeberle and Rolf Gindorf (New York: Continuum, 1998), 88.

116. Yoshino, 'The Epistemic Contract of Bisexual Erasure', 404-10.

117. Ibid., 407. 
118. For an example of an essentialist approach to constitutional sexual minority rights jurisprudence in Canada, see e.g., Egan v. Canada, 528 (holding that sexual orientation is a constitutionally prohibited ground of discrimination because sexual orientation 'is a deeply personal characteristic that is either unchangeable or changeable only at unacceptable personal costs'). For a persuasive critique of this aspect of Egan, see Robert Leckey, 'Chosen Discrimination', Supreme Court Law Review (2d) 18 (2002): 445. For a discussion of the role of essentialist arguments in United States constitutional equality jurisprudence involving sexual minorities, see Halley, 'Sexual Orientation and the Politics of Biology'; Kari Balog, 'Equal Protection for Homosexuals: Why the Immutability Argument is Necessary and How it is Met', Cleveland State Law Review 53 (2006): 545; Yoshino, 'The Epistemic Contract of Bisexual Erasure', 405.

119. Michael Kirby, 'Sexuality and Australian Law', Journal of Homosexuality 48, nos 3-4 (2005): 31, 33.

120. Ibid., 32. See also note 93 and accompanying text above.

121. Yoshino, 'The Epistemic Contract of Bisexual Erasure', 401-2.

122. Joan, 'This Is Me', in Bisexual Horizon, ed. Sharon Rose and Cris Stevens (London: Lawrence \& Wishart, 1996), 142: '[Bisexuality] is obviously a part of me, how nature made me, and there's no use in trying to fight against it.'

123. Gagnon et al., 'Bisexuality', 99; Simon Scott, 'Politically Bi', in Rose and Stevens, Bisexual Horizon, 236.

124. Liz Highleyman, 'Thoughts of a Bisexual Anarchist', in Rose and Stevens, Bisexual Horizon, 271.

125. Marie King, 'It Could Be Either', in Rose and Stevens, Bisexual Horizon, 105.

126. Dave Matteson, 'Bisexual Feminist Man', in Bi Any Other Name: Bisexual People Speak Out, ed. Loraine Hutchins and Lani Kaahumanu (Boston, Alyson, 1991), 47.

127. Starhawk, 'The Sacredness of Pleasure', in Bisexual Politics: Theories, Queries \& Visions, ed. Naomi Tucker (New York: Hawthorne Press, 1995), 327.

128. Yoshino, 'The Epistemic Contract of Bisexual Erasure', 428-9.

129. This phenomenon goes some distance towards explaining the infrequent references to bisexuality by the human rights tribunals and organisations noted at the beginning of the paper. See notes $2-10$ above and accompanying text.

130. RRT Reference: $N 95 / 07313$.

131. Ibid.

132. Ibid. (emphasis added).

133. Ibid.

134. Ibid.

135. Alternor v. Canada, 2008 FC 570, [2008] FCJ No. 731.

136. RPD File No. TA6-12910 (18 July 2007) (on file with author), overturned by Alternor v. Canada (emphasis added). The author would like to thank Richard Odeleye for providing a copy of the decision.

137. Elias Farajajé-Jones, 'Fluid Desire: Race, HIV/AIDS and Bisexual Politics', in Bisexual Politics: Theories, Queries \& Visions, ed. Naomi Tucker (New York: Hawthorne Press, 1995), 119-20. See also Kirsten McLean, 'Negotiating (Non)Monogamy: Bisexuality and Intimate Relationships', in Current Research on Bisexuality, ed. Ronald Fox (Binghamton, NY: Harrington Park Press, 2004), 85; Amanda Udis-Kessler, 'Challenging the Stereotypes', in Bisexual Horizon, ed. Sharon Rose and Cris Stevens (London: Lawrence \& Wishart, 1996), 45-57 esp. 50.

138. K.O.C. (Re) [2003] RPDD No. 420, 11 .

139. Gyorgyjakab v. Canada (Minister of Citizenship and Immigration) [2004] RPDD No. 698, 43.

140. Colker, Hybrid, 28.

141. William Burleson, Bi America: Myths, Truths and Struggles of an Invisible Community (New York: Harrington Park Press, 2005), 45.

142. Felicity Cade, 'Marriage and Bisexuality', in Bisexual Horizon, ed. Sharon Rose and Cris Stevens (London: Lawrence \& Wishart, 1996), 114: 'I am a happily married bisexual feminist with other lovers of both genders, and playmates whose gender I would not dare to predict.'

143. See generally Annie Murray, 'Forsaking All Others: A Bifeminist Discussion of Compulsory Monogamy', in Bisexual Politics: Theories, Queries \& Visions, ed. Naomi Tucker (New York: Hawthorne Press, 1995), 293; Burleson, Bi America, 119-23. 

144. Rifka Reichler, 'A Question of Invisibility', in Bi Any Other Name: Bisexual People Speak Out, ed. Loraine Hutchins and Lani Kaahumanu (Boston, Alyson, 1991), 77.

145. This case was upheld on judicial review: SZJSL v. Minister for Immigration and Multicultural Affairs and Another.

146. Ibid.

147. RRT Reference: N05/50659 [2005] RRTA 207 (17 May 2005) (emphasis added).

148. Millbank, 'Gender, Sex and Visibility in Refugee Claims on the Basis of Sexual Orientation', 93. 